\title{
Building The Values of Environmental Awareness Through
}

\section{The Adiwiyata School}

\author{
$1^{\text {st }}$ Sarbaini \\ Social Studies Education Master Program of \\ ULM Banjarmasin, Banjarmasin, Indonesia \\ $2^{\text {nd }}$ Syaharuddin* \\ Social Studies Education Master Program of \\ ULM Banjarmasin,Banjarmasin, Indonesia \\ Syahar@ulm.ac.id
}

\author{
$3^{\text {rd }}$ Ma'nawiyah \\ Teacher of Social Studies Education at SMP \\ Negeri 27 Banjarmasin, Banjarmasin, Indonesia
}

\begin{abstract}
Nowadays, the global environmental condition is expanding and worrying the future of human being. It is triggered by the behavior of humans who exploit natural resources and environment without limit. Formal education has strategic function to plant the environmental caring values character through Adiwiyata School. This research aims to describe the planting strategy of environmental caring values characterin public junior high school 27 Banjarmasin. The approach of this research is qualitative. The data was collected through interview, observation, and document study. The data analysis started from data reduction, data presentation, and verification/conclusion. The validity technique of the data was by using
\end{abstract}

\section{INTRODUCTION}

Human life can not be separated from environmental issues. Environment and humans have a reciprocal relationship that shapes human behavior in life. The well-managed environment will have a positive impact on residents and vice versa.Utilize human nature and the surrounding environment to improve their welfare [1]. In some regions, it becomes a crutch for their economic development, but not a few who had to sacrifice the community because of the resulting negative impact, such as floods, landslides, and the smoke caused burnt forest. Man in keeping in touch with their cultural environment [2]. Habituation keeps the school triangulation, research extension, and members check. The research result was, namely: the implementation strategy of environmental caring values in public junior high school 27 Banjarmasin was done through: 1) selfdevelopment (routine activities, spontaneous activities, exemplary, conditioning), 2) integration insubject lesson, and 3) school's culture. The forms of environmental caring values implementation were reflected through class picket activity, "Five Minutes Movement" before entering the classroom in the first hour, and the "Clean Friday" activity.

$$
\begin{gathered}
\text { Keywords-Values, } \\
\text { Awareness, Adiwiyata School }
\end{gathered}
$$

environment will form the knowledge and behavior of students always keep the environment clean and beautiful looks.

Environmental problems in this country are still unresolved, although Indonesia in some ways superior to all countries in Asia to cope with environmental issues, particularly those related to reducing emissions and increasing carbon sequestration [3]. Some of them are caused by the human nature as a creature economy which then performs various activities for its needs, such as exploiting the massive nature that eventually destroys nature and the environment and a negative impact on human life. Study Results The Ministry of Environment 
(MOE) Indonesia (2012), indicates that the Environmental Care Behavior Index still stood at approximately 0.57 (from an absolute figure 1). This indicates that Indonesian society is not yet fully in the running of everyday life behaves a caring environment [4].

Care for the environment is the protection and management of the environment, to address environmental issues, as well as supporting sustainable development. Then schools through various programs initiated by setting the vision and mission of the school are among the solutions. The school has a strategic role in the efforts to build awareness in the neighborhood. Through various programs, such as Flirtatious Movement (five minutes), LISA (see garbage), and "Clean Friday Movement" in public junior high school 27 Banjarmasin, it is expected that students awakened environmental consciousness.Also, the entire school community, ranging from nutmeg school until the caretaker should play a role in understanding and give examples of behaviors that demonstrate the value of environmental care. This is important because students tend to copy what is done by the adults around them, children see children do [4].

Public junior high school 27 Banjarmasin is one Adiwiyata School in London in 2015. This school has implemented a government program to create awareness and awareness of the school community towards the school environment. Therefore, Adiwiyata's implementation in school is very important to raise environmental awareness through education. Implementation Program Adiwiyata in public junior high school 27 Banjarmasin not fully guarantee an increase in environmental awareness for students. This marked still some students are not concerned with the environment so that the necessary effort to overcome these problems by increasing awareness and awareness of students to the school environment through the implementation of Adiwiyata.

Research on environmental concerns ever undertaken by Elsa [5]. She argues that implementation of character education care for the environment can improve understanding and lead to changes in attitudes and behavior of students to become aware of and concerned about the environment on the concept of pollution and environmental damage. Mulyana[6] found that environmental education is done in schools, effective in instilling a concern for the preservation of natural resources and the environment.

Strategy to build awareness of environmental characteristics such as through school culture that implementation can be done through behavioral dispose of waste in place, maintaining the cleanliness of the toilets, implement programs daily pickets, loving plants around the school and remind people around so environmental hygiene is maintained[7].

Environmental education is an integrative action by doing teaching through a variety of disciplines to help students understand the environment in complex and environmental awareness [8]. A multidisciplinary approach will provide insight to students about the issues and how to address the current and emerging environment.Various explanations about this research focused on efforts to build awareness of environmental values for students at public junior high school 27 Banjarmasin.

\section{METHOD}

This study used a qualitative approach for describing the implementation of the values of the environmental awareness of students in public junior high school 27 Banjarmasin.Subject of this research is the principal, headteacher and the staff of administration, and builder Adiwiyata schools as well as students of public junior high school 27 Banjarmasin. Data were obtained through interviews by subject research. Observations were made to describe the environmental conditions and practices of students in developing the values of environmental awareness. Studies document to analyze the facts and concepts that want to develop schools that appear on the vision and mission and Adiwiyataschool in public junior high school 27 Banjarmasin. Data analysis techniques to follow the model of Miles and Huberman[9]. The presentation of data is done using a narrative to describe the implementation in building the values of environmental awareness in public junior high school 27 Banjarmasin. Such data validity through triangulation to obtain accurate data from many different sources about school 
efforts to build awareness of environmental values for students at public junior high school 27 Banjarmasin.

\section{RESULTS AND DISCUSSION}

Implementation of character values including the value of environmental care at the unit level of education, is based on great planning [10] that is contained in the "Implementation Guidelines Character Education in Schools". The value of environmental care is school policy. That policy has been stated in the vision and mission of public junior high school 27 Banjarmasin. The vision that reads "Produce students who are honest, insightful Science and Technology, Arts and Culture are grounded IMTAQ as well as hygiene and beauty care environment". While the mission associated with the implementation of environmental value reads "Growing awareness of the school community in keeping/ maintaining cleanliness and realize the beautiful, green environment as well as raising awareness of the school community to join the movement like planting trees".

According to the principal, Hapni [11] that the implementation of environmental care is a direct policy of the school and is the collective responsibility of the entire school community. This policy is made in the rules/school rules. Activities conducted in schools show an effort to prevent environmental damage and preserve the environment, such as the establishment of a 'green army' of students with the task of handling the problem of garbage and planting trees in the yard. The program integrates well with the student council activities [12], [13], [14].

Implementation of environmental care to establish the values of environmental awareness for students through the Adiwiyata program is the school policy contained in the vision and mission. To prevent damage to the environment, the school seeks to undertake tree planting and plants around the school and efforts to improve the environmental damage by monitoring and providing guidance to learners, particularly related to the problem of waste.

Strategy implements the values in character education at the unit level education focused on the value of environmental care can be done through a self-development program consisting of routine, spontaneous activity, modeling, and conditioning. The second strategy through the integration of subjects, as well as school culture [15].

Self Development Program for Establishing Values Environmental Awareness

1. Routine activities: Daily Piket Schedule for Students

According to Events Calendar [10] that the regular activities of the school is an activity that learners are constantly and consistently every day. The routines in public junior high school 27 students Banjarmasin performed daily as a class picket i.e. cleaning classrooms and the surrounding environment. According to Hapni [11] suggests that one of the school programs is to realize the cultivation of a caring attitude towards the environment. For that responsibility to do all the school community. To perform the conditioning of children to the surrounding environment is called upon to all homeroom so that no division of duties evenly. The goal is that the students used to maintain the cleanliness class and their respective communities.

Routine activities are implemented as classes scheduled picket, flirty program (movement five minutes), the school program with the motion five minutes after the march before entering the first hour. Students see and care about the state of the surrounding environment both inside and outside the classroom. LISA program (see litter), children see junk and picking up litter and then throw it into the trash. The program is implemented at any time, morning or afternoon [12].

Students 'views related to routine activities to build students' awareness of the environmental values, do a few things, namely through the picket schedule activities that have been written on the wall. Picket held mornings and after school with classroom cleaning, tidying up chairs and tables, cleaning the blackboard and watering. In practice, the students do in work together [16], [17], [18], [19]. Observations from class VIII public junior high school 27 (6 April 2018) still some students do not carry picket class. That's because the students were on duty late. This shows the lack of awareness of students' responsibilities. 
2. Spontaneous activity: Must be Backed Rules of the Schools

According to the Ministry of National Education [20], spontaneous activity is activities carried out spontaneously at the moment. Spontaneous activities conducted student at public junior high school 27 Banjarmasin be related to the behavior or attitude that is positive or negative. Spontaneous activities take place regarding positive and negative student behavior. As for positive behavior as a form of implementation of the care for the environment, such as taking out the trash in its place through a variety of programs flirtatious (movement five minutes), LISA (see garbage), and "Clean Friday".According to Syarifah Rugayah [21] that there are rules contained in the school rules which states that all students must keep their environment, ie, not littering. Cooperation carried out with the homeroom teachers to urge all students to not litter. Each homeroom has an agreement with each of their students. Students who do not comply with the rules repeatedly will be developed by the conselingteacher.

The school is the educational environment intentionally designed and implemented with strict rules and receives direct supervision from the government [22]. Therefore, the order of importance related to the preservation of the environment is made and implemented. Although it has no rules about maintaining the cleanliness of the school and students are used to throw garbage in the dustbins provided, but there are still students who throw garbage is not in place, such as under the reservoir, river, under the table, in the garden and the windows [23], [24].

The teacher's role is important in building environmental awareness for students. Teachers reprimand students when littering. Teachers also instructed students to clean the classroom after school and dispose of their garbage. Students who dispose of waste in place would be given the appreciation in the form of a thumbs up and positive words, such a nice and smart [25]. Results of observation (6 April 2018) looks at class VII litter. A teacher who happened to be passing asks the students to pick it up and throw it in place. On the same day at 12:10 hour second break, one of the students of class VIII littering and reprimanded by his colleagues to dispose of the waste in place.

Implementation strategies that do care about the environment of the school show that the attitude and behavior of the positive learners who are good enough and needs to be improved so that it can be used as a model for other friends. Meanwhile, the spontaneous activity of the attitudes and negative behaviors performed as a form of understanding and guidance on how attitudes and behavior. For example, providing advice and warning if violations are found littering.The attitude of care for the environment a character to be developed in the school. Spontaneous activities conducted at public junior high school 27 Banjarmasin quite an impact on the formation of attitudes caring environment for students. Care for the environ ment is among the types of environment-based character education [26]. This concept is quite important to be developed through various activities at school, such as spontaneous activities of the school community to the environmental conditions.

3. Modeling: Teachers Become Key to Success

According to the Ministry of National Education [20], that is exemplary behavior and attitudes of principals, teachers, and educators in providing a good example to the learners. Modeling is practiced, practiced and not just preached, fought, manifested, and proved [26]. Teachers and all school members should practice exemplary in maintaining the school environment, either through program flirty, LISA and "Clean Friday" and various other programs. Teachers and the school community should pay more examples than advised.Modeling is important in the educational process at school. Residents of schools, both principals, teachers, staff Administration (TU), and the caretaker is a figure for students. Planting values required environmental awareness in schools exemplary by the school community, especially teachers. Modeling the key to school success in instilling the values of environmental awareness.

Modeling for teachers and the entire school community towards environmental awareness has implications for the formation of students' attitudes towards the environment. Care for the environment is the attitude and action which 
seeks to prevent damage to the surrounding natural environment, and develop efforts to repair the environmental damage that has occurred [27]. Public junior high school 27 Banjarmasin has conducted various programs to build environmental awareness for students. Character education care for the environment are: (1) Allowing maintaining cleanliness and sustainability in the school environment; (2) Provide bins and handwashing; (3) Provide showers and clean water; (4) Provide cleaning equipment [28].

Results observation (6 April 2018) in public junior high school 27 looks all students of class IX with the teachers planted in the front yard of their respective classes. This activity is carried out of the school in stages. Students are excited and happy to do this greening activity that the school looks beautiful and clean. The role of teachers is very important to encourage the school community has a caring attitude environment. He should be a role model for students to environmental issues. Some forms of activities undertaken related to efforts to build environmental awareness, which is carrying out reforestation and waste disposal. All was done with pleasure [29], [11].

Modeling has a huge contribution in shaping the character [30]. Teachers are the main role models for students in the school. The seriousness of teachers in guiding students to the values of environmental awareness will impact large enough for a change of attitude. Therefore, the teacher is key to success in building the values of environmental awareness for students.

4. Conditioning: Start of Supply Facility until Slogan

According to the Ministry of National Education [20], conditioning is a business school to support the establishment and implementation of environmentally conscious character. Conditioning is done by the school such as the form of the provision of adequate sanitary facilities, provision of clean toilets, bins are placed in strategic places equipped with the segregation of garbage, provision of handwashing facilities, landfills, as well as a garden and a swimming school as a reflection of sanitation a good school.
As one embodiment of the enforceability of the character education schools should be 'conditioned' to support environmentally friendly school programs. Some programs that reflect the value of environmental care in public junior high school 27 Banjarmasin, among others: (a) planting herb, as the learning environment and (b) provide bins based on the type of waste that is scattered in some corner of the school. (c) implementthe rules of cleanliness and environmental sustainability of the school, (d) conducting the movement of love cleanliness and health of the school environment.Schools also create slogans such as words of wisdom to inspire students. Slogan placed at strategic places that were easily visible to students. Some slogans such as "Clean Healthy Base", "Cleanliness is a Part Of Faith", "Maintain Cleanliness", "Come Clean and Healthy". All it aims to Building awareness of environmental values through integration in subjects

According to Events Calendar [10] express attitudes and behaviors and instill environmental awareness can be applied through the school curriculum and the learning process. The integration of character education in the subjects of environmental care can be done by several things, including specifying the values of environmental awareness on the syllabus, lesson plan.

Implementation of the educational value of environmental care in public junior high school 27 Banjarmasin implemented through integration in subjects like social studies, natural sciences, islamic education, physical and health education, indonesian, and arts and a craft.

Two subjects in school are described namely IPS and IPA at the basic education level (SMP / MTs). Social studies education material class VIII on environmental issues, such as floods, pollution, and global warming issues. Through pictures and methods of discussion, the students can identify the causes of these problems. Students are also able to understand the impact of and efforts to overcome them. VIII grade science subjects in an environmental matter concerning waste management, students are invited to apply the proper sorting of waste and litter. 
Integrating environmental care education in the learning process can not be separated the guidance of teachers. In the process of learning, teachers use the environment as a learning medium. The neighborhood around the media should be part even of learning resources for students in various subjects. This is done by teachers to integrate the value of environmental care through lessons at school.

School Culture to Build Concern for the Environment

Events Calendar [10] states that the school culture is the atmosphere of the school in which the students interact with peers, principals, teachers, and other school community. In a broader sense, the culture of the school is a set of norms, values, traditions, symbols, custom-built for a long time by all school members [31], [32].

The educational value of environmental care in the context of school culture that developed in public junior high school 27 Banjarmasin namely through a program prepared by schools based on the vision and mission of the school, such as programs to maintain cleanliness, beauty, and maintenance of the environment. The implement tation of environment-related school programs seems effective. According to Daryanto [32], one of the characteristics of effective schools is the creation of the school culture and climate enjoyable so that students feel safe, comfortable, and orderly in their learning.

School culture has a strategic function to build awareness of the environment for the school community, by developing school programs, such as hygiene picket schedule, program flirty LISA program and "Clean Friday". To support this, the necessary means in the form of a tool, such as a broom, dustpan and trash [11], [33].

Results observation (6 April 2018) on the development of the school culture, it seems students cleaning the classroom every morning and after school hours ended interchangeably. To support these activities, the school is required to provide the ingredients, such as broom, dustpan, bucket, mop the floor, and trash. Before entering the classroom do the flirtatious program conducted simultaneously by all students with teacher supervision. LISA program carried out at any time. The program "Clean Friday" do school once a month, accompanied by guardians class.

Efforts to protect the environment are described in [34] Law No. 32 of 2009 Article 1 (2), the point that the protection and management must be done systematically and through planning. A related school culture of environmental preservation in public junior high school 27 Banjarmasin done systematically beginning of the vision and mission for the program flirty, LISA and "Clean Friday".

\section{CONCLUSIONS}

Strategy to build awareness of environmental values in public junior high school 27 Banjarmasin done through the program "selfdevelopment" consisting of components (a) routine activities, (b) spontaneous activity, (c) pattern, and (d) conditioning. The four components are effective in building environmental awareness of the values of students through various programs in the vision and mission of the school. The programs carried out through the "movement five minutes" (flirtatious), "see trash" (LISA), and "Clean Friday" and slogans that aim to remind and motivate people in schools to maintain the environment to keep it clean, beautiful, healthy, and beautiful.

The second strategy with the integration program in the subjects.Subjects that can be integrated in the Social Studies, Science, Religion, Physical Education, Indonesian, and Arts and craft. The second strategy is capable of delivering knowledge to students about various environmental issues including efforts to overcome to reduce its impact on society. The third strategy through the cultural program of the school.School culture in public junior high school 27 Banjarmasin done through the efforts of the school community, from the principal to the school caretaker in maintaining and preserving the environment to make it look clean, beautiful, healthy and beautiful and comfortable.

\section{ACKNOWLEDGMENTS}

Thank you to all those who have been involved in writing this article. 


\section{REFERENCES}

[1] Rusdina, A. (2015). Membumikan Etika Lingkungan bagi Upaya Membudayakan Pengelolaan Lingkungan yang Bertanggung jawab. Jurnal Istek, IX(2). Tersedia

http://journal.uinsgd.ac.id.Diakses tanggal 6 Juli 2018.

[2] Taufiq, Ahmad. (2014). Upaya Pemeliharaan Lingkungan oleh Masyarakat di Kampung Sukadaya Kabupaten Subang. Jurnal Gea, 14(2).Tersedia http:// download. portal garuda. org. Diakses Tanggal 6 Juli 2018.

[3] Rajiani I., Pypłacz P. (2018). National Culture as Modality in Managing The Carbon Economy in Southeast Asia. Polish Journal Of Management Studies, 18(1).

[4] Ngalawiyah, Lutfi. (2014). Studi Implementasi Nilai Peduli Lingkungan Menuju Sekolah Adiwiyata Di SDN Tukangan Yogyakarta". Skripsi. Fakultas Ilmu Pendidikan Universitas Negeri Yogyakarta. Retrieved from http://eprints.uny.ac.id. Diakses tanggal 20 Oktober 2017.

[5] Elsa, Femilia. (2014). Penerapan Pendidikan Karakter Peduli Lingkungan Melalui Metode Inkuiri terhadap Sikap dan Perilaku Siswa pada Materi Pencemaran dan Kerusakan Lingkungan di SMP Negeri 6 Banda Aceh. Biotik: Jurnal Ilmiah Biologi Teknologi dan Kependidikan. Retrieved from http://jurnal.arraniry.ac.id. Diakses tanggal 26 November 2017.

[6] Mulyana, Rachmat. (2009). Penanaman Etika Lingkungan Melalui Sekolah Pedulidan Berbudaya Lingkungan. Jurnal Tabularasa PPS Unimed, 6(2). Retrieved from http://digilib. unimed.ac.id. Diakses tanggal 26 November 2017.

[7] Al-Anwari, Amirul Mukminin. (2014). Strategi Pembentukan karakter Peduli Lingkungan Di Sekolah Adiwiyata Mandiri Amirul Mukmini. Jurnal Ta'dib, XIX(2). Retrieved from http://jurnal. radenfatah.ac.id. Diakses tanggal 26 November 2017.
[8] Karrow, D, Douglas. (2015). Curriculer Critique of an Environmental Education Policy: Implications for Practice. Brock Education Journal, 24(2). Retrieved from http://files.eric.ed.gov. Diakses tanggal 10 Juni 2010.

[9] Miles, M.B dan Huberman, A.M. (1992). Analisis Data Kualitatif. Jakarta: UI Press.

[10] Kemendiknas. (2010). Pengembangan Pendidikan Budaya dan Karakter Bangsa, Bahan Pelatihan Penguatan Metodologi Pembelajaran Berdasarkan Nilai Budaya Untuk Membentuk Daya Saing dan Karakter Bangsa. Jakarta: Badan Penelitian dan Pengembangan Pusat Kurikulum. Tersedia: www. Sman 78 jkt.sch.id. Diakses 25 Pebruari 2018.

[11] Hapni, Drs. MM. Pekerjaan: Kepsek SMPN 27 Banjarmasin. Alamat: Banjarmasin. Wawancara 6 dan 19 Maret 2018.

[12] Akhmad Damiri, S.Pd. Pekerjaan: Guru SMPN 27 Banjarmasin. Alamat: Banjarmasin. Wawancara 27 Maret 2018.

[13] Rabiatul Adawiyah, S.Pd. Pekerjaan: Guru SMPN 27 Banjarmasin. Alamat: Banjarmasin. Wawancara 27 Maret 2018.

[14] Yahya. Pekerjaan: Bidang Pembinaan SMP Dinas Pendidikan Kota Banjarmasin. Alamat: Banjarmasin. Wawancara 27 Maret 2019.

[15] Su'ud, Abu, 2008. Revitalisasi Pendidikan IPS. Semarang: Unnes Press.

[16] Norlita Damayanti. Pekerjaan: Siswa Kelas VIIA SMPN 27 Banjarmasin. Alamat: Banjarmasin. Wawancara 21 Maret 2019.

[17] M. Fazri.Pekerjaan: SiswaKelas IXC SMPN 27 Banjarmasin. Alamat: Banjarmasin. Wawancara 21 Maret 2019.

[18] Maulidya. Pekerjaan: Siswa Kelas VIIID SMPN 27 Banjarmasin

[19] Puji Hastuti. Pekerjaan: SiswaKelas IXA SMPN 27 Banjarmasin. Alamat: Banjarmasin. Wawancara 23 Maret 2019.

[20] Kemendiknas. (2010). Pengembangan Pendidikan Budaya dan Karakter Bangsa, Bahan Pelatihan Penguatan Metodologi Pembelajaran Berdasarkan Nilai Budaya Untuk Membentuk Daya Saing dan Karakter Bangsa. Jakarta: Badan Penelitian dan 
Pengembangan Pusat Kurikulum dan Perbukuan.

[21] Sarifah Rugayah, S.Pd. Pekerjaan: Guru SMPN 27 Banjarmasin. Alamat Banjarmasin. Wawancara 24 Maret 2019.

[22] Sadulloh, Uyoh. (2010). Pedagogik (IlmuMendidik). Bandung: Alfabeta.

[23] Daryl David Huwae. Pekerjaan: Siswa Kelas IXD SMPN 27 Banjarmasin. Alamat: Banjarmasin. Wawancara 22 Maret 2019.

[24] Satriadi. Pekerjaan: SiswaKelas VIIIC SMPN 27 Banjarmasin. Alamat: Banjarmasin. Wawancara 22 Maret 2019.

[25] Kamariah, S.Pd. Pekerjaan: Guru SMPN 27 Banjarmasin. Alamat Banjarmasin. Wawancara 6 Maret 2018.

[26] Asmani, Jamal Ma'mur. (2012). Buku Panduan Internalisasi Pendidikan Karakter di Sekolah. Yogyakarta: Diva Press.

[27] Daryanto dan Suryatri Darmiatun. (2013). Implementasi Pendidikan Karakter di Sekolah.Yogyakarta: Gava Media.
[28] Fathurrohman, Pupuh dkk. (2013). Pengembangan Pendidikan Karakter. Bandung: Refika Aditama.

[29] Reyna Citra. Pekerjaan: Kelas VII G. Alamat: Banjarmasin. Wawancara 23 Maret 2019.

[30] Rahmad. (2016). Kedudukan Ilmu Pengetahuan Sosial (IPS) pada Sekolah Dasar. Muallimuna Jurnal Madrasah Ibtidaiyah. Vol.2. No.1 Oktober 2016. ISSN:2476-9703. Retrieved from hhtp://media.neliti.com. Diakses tanggal 10 Juni 2018.

[31] Hanifah. (2014). Budaya Sekolah Islami. Retrieved from http://eprints. walisongo. ac. id. Diakses tanggal 24 Mei 2018.

[32] Daryanto. (2015). Pengelolaan Budayadan Iklim Sekolah. Yogyakarta: Gava Media.

[33] Rusdiana, S.Ag. Pekerjaan: Guru SMPN 27 Banjarmasin. Alamat Banjarmasin. Wawancara 31 Maret 2018.

[34] Undang-Undang RI No. 32 Tahun 2009 tentang Perlindungan dan Pengelolaan Lingkungan Hidup. 